Article 265

Received: Octoberr 20, 2019

Accepted: November 4, 2019
Macedonian Journal of Animal Science, Vol. 9, No. 2, pp. 45-51 (2019)

In print ISSN $1857-6907$

On line ISSN $1857-7709$

UDC: $637.5 ' 652 / 658.053 / .054:[636.52 / .58 .086 .7: 633.88$

Original scientific paper

\title{
EFFECTS OF MEDICINAL PLANTS IN BROILER CHICKEN NUTRITION ON SELECTED PARAMETERS OF MEAT QUALITY
}

\author{
Nikola Puvača **, Tatjana Peulić2 , Predrag Ikonić2, Sanja Popović ${ }^{2}$, Jasmina Lazarević2, \\ Olivera Đuragić ${ }^{2}$, Magdalena Cara ${ }^{3}$, Nedeljka Nikolova ${ }^{4}$ \\ ${ }^{1}$ Department of Engineering Management in Biotechnology, \\ Faculty of Economics and Engineering Management, University Business Academy, \\ Cvećarska 2, 21000 Novi Sad, Serbia \\ ${ }^{2}$ Institute of Food Technology, University of Novi Sad, \\ Bulevar cara Lazara 1, 21000 Novi Sad, Serbia \\ ${ }^{3}$ Faculty of Agriculture and Environment, Agricultural University of Tirana, \\ Koder Kamez, 1029 Tirana, Albania \\ ${ }^{4}$ Institute of Animal Science, University "Ss. Cyril and Methodius", \\ Av. Ilinden 92/a, 1000 Skopje, North Macedonia \\ nikola.puvaca@gmail.com // nikola.puvaca@ fimek.edu.rs
}

\begin{abstract}
A b s t r a c t: The use of nutritional strategies to improve the quality of meat is a relatively new approach that has emerged at the interface of animal science and food science. The effects of dietary garlic, black pepper and hot red pepper addition to chicken nutrition on quality characteristics of breast and thigh with drumstick meat were investigated. Quality measurements included meat physical ( $\mathrm{pH}$, color $-\mathrm{CIE} L^{*} a * b^{*}$ and drip-loss) and chemical (moisture, protein, fat and ash content) characteristics. Medicinal plants showed significant $(\mathrm{p}<0.05)$ influence in altering most examined quality parameters of chicken meat, especially when adding red hot pepper. In conclusion, medicinal plants had a positive influence on chicken meat quality, however, the knowledge of their mode of action is still limited and thus requires further investigation.
\end{abstract}

Key words: medicinal plants; nutrition; meat quality

\section{ВЛИЈАНИЈА НА ЛЕКОВИТИ РАСТЕНИЈА ВО ХРАНАТА НА БРОЈЛЕРСКИ ПИЛИЫА ВРЗ ОДРЕДЕНИ СВОЈСТВА ЗА КВАЛИТЕТ НА МЕСО}

А п с т р а к т: Користењето на нутритивни стратегии за подобрување на квалитетот на месото е релативно нов пристап кој се појави на интерфејсот во науката за животни и науката за храна. Истражени се влијанијата на додавање на лук, црн пипер и лута црвена пиперка во исхраната кај бројлерски пилиња врз квалитативните својства на месот од градите, копанот и надкопанот. Мерењата на квалитетот ги вклучуваа физичките (pH, боја - CIE L* a* b* и загуба на течности) и хемиските својства (содржина на влага, протеини, масти и пепел) на месото. Лековитите растенија покажаа значително $(\mathrm{p}<0,05)$ влијание со менување на повеќето испитувани квалитативни својства на пилешкото месо, особено при додавање на црвена лута пиперка. Како заклучок, лековитите растенија имаа позитивно влијание врз квалитетот на пилешкото месо, меѓутоа, познвањето на нивниот начин на делување е сѐ уште ограничен и затоа бара дополнителна истрага.

Клучни зборови: ековити растенија; исхрана; квалитет на месо 


\section{INTRODUCTION}

In the last decade, consumers have become more concerned about the processed food they consume. Synthetic preservatives, which have been used in the food industry, may lead to negative health consequences. The use of synthetic compounds has significant drawbacks, such as increasing cost, handling hazards, concerns about residues on food and threat to the human environment. Therefore, there has been increasing interest to replace synthetic with natural, effective and non-toxic compounds $[1,2]$. Those, in the first place, are extracts and essential oils [3, 4], spices [5, 6] and medicinal plants $[7,8]$. As natural foodstuffs, spices and medicinal plants appeal to all who question the safety of synthetic food additives and demand high-quality products that at the same time are safe and stable.

Medicinal plants have been extensively used in the therapy of some diseases for a long time. Interest in plants, plant extracts, and derived phytochemicals as components of livestock feedstuffs has increased during the last years [9]. Moreover, medicinal plants and aromatic plants possess many antioxidants that are effective in preventing oxidative changes and, thus, can minimize off-odor production in meat [10]. The use of nutritional strategies to improve the quality of meat is a relatively new approach that has emerged at the interface of animal science and food science $[11,12,13]$. Nutritional approaches are often more effective than the direct addition of the additive to meat since the compound is preferably deposited where it is most needed [14]. As in other animal species, the physical quality of broiler meat is of major importance, since broiler chicken meat is nowadays usually consumed as cuts or as processed products rather than as whole carcasses.

Physical quality refers to several meat properties, including $\mathrm{pH}$ and color values. Meat quality is closely related to the decrease in muscle $\mathrm{pH}$ postmortem. Rapid postmortem decline in $\mathrm{pH}$ results in PSE (pale, soft and exudative) meat with a pale aspect and reduced water-holding capacity [15]. The variations in the colour of broiler breast meat fillets are significantly correlated with muscle $\mathrm{pH}$ and extremes in color variations [16]. Low ultimate $\mathrm{pH}$ results in "acid meat", with similar defects to those of PSE meat [17], while high ultimate $\mathrm{pH}$ leads to DFD (dark, firm and dry) meat with dark color and poor storage quality [18].

Besides physical meat quality, economic importance is also related to sensory and chemical characteristics of meat which should not be forgot- ten. To ensure optimum quality, it is necessary to consider the entire production chain from farm to fork [16]. Many studies focused on the impact of many dietary supplemental components with the aim to find more efficient alternatives or combinations of different alternatives for maintaining health and improving the performance of poultry and meat quality and safety, without antibiotics residues.

Therefore, the aim of this study was to investigate the influence of garlic, black pepper and hot red pepper in the broiler diet on meat physical and chemical characteristics.

\section{MATERIALS AND METHODS}

\section{Animal housing and nutrition}

Biological tests were carried out under production conditions. All experimental procedures have been approved by the competent Veterinary Authority according to the National legislation (Presidential Decree 56/2013 on harmonization of the Directive 2010/63/EU on the protection of animals used for scientific purposes) under registered number I2015-02. At the beginning of the experiment, a total of 1200 one-day-old Hubbard broilers strain, of mixed-sex, were distributed into eight dietary treatments with four replicates each (Table 1).

\section{Table 1}

\section{Experimental design with chickens and dietary} treatments, $\mathrm{g} / 100 \mathrm{~g}$

\begin{tabular}{|c|c|c|c|c|}
\hline \multirow{3}{*}{ 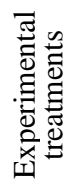 } & \multicolumn{4}{|c|}{ The concentration of additives in chicken diets } \\
\hline & & Starter & Grower & Finisher \\
\hline & Additive & $\begin{array}{c}1-14 \\
\text { days }\end{array}$ & $\begin{array}{l}15-35 \\
\text { days }\end{array}$ & $\begin{array}{c}36-42 \\
\text { days }\end{array}$ \\
\hline $\mathrm{T} 1$ & Control treatment & 0.0 & 0.0 & 0.0 \\
\hline $\mathrm{T} 2$ & Garlic powder & 0.0 & 0.5 & 0.5 \\
\hline $\mathrm{T} 3$ & Garlic powder & 0.0 & 1.0 & 1.0 \\
\hline $\mathrm{T} 4$ & Black pepper powder & 0.0 & 0.5 & 0.5 \\
\hline T5 & Black pepper powder & 0.0 & 1.0 & 1.0 \\
\hline T6 & Hot red pepper powder & 0.0 & 0.5 & 0.5 \\
\hline $\mathrm{T} 7$ & Hot red pepper powder & 0.0 & 1.0 & 1.0 \\
\hline $\mathrm{T} 8$ & $\begin{array}{l}\text { Mixture of garlic, black pepper } \\
\text { and hot red pepper }(1: 1: 1)\end{array}$ & 0.0 & 0.5 & 0.5 \\
\hline
\end{tabular}


Every dietary treatment included 150 chickens, which were divided into four pens (37-38 chicken per pen). The feeding program included a three-phase diet as a starter, grower and finisher, respectively. For the first 14 days, during the acclimation period, chicks were fed with a starter diet, then birds were fed with a grower diet for the next 21 days and then for the last 7 days of fattening period with finisher diet. During the whole trial feed and water were provided ad libitum. Microclimate conditions were regularly monitored. Rearing and housing conditions were previously described in detail by Puvača et al. [5], while the nutrition of the chickens was previously described in detail by Puvača et al. [12].

\section{Sample collections}

At the end of the $42^{\text {nd }}$ day of the experiment, 12 broiler chicks, six male and six female of average body weight of each treatment group were selected for meat quality evaluations. Before slaughtering broiler chickens were starved for $12 \mathrm{~h}$, and afterword slaughtered were processed by bloodletting, scalding, plucking and evisceration and chilling. Upon slaughter, dressed cold carcasses were dissected into primal cuts such as breast, thighs with drumsticks, wings, back, head, neck and legs following the method prescribed by the Regulation on Poultry Meat Quality (Official Gazette of the SFRY No. 1/81 and 51/88). After 24 hours of post-mortem breast (Musculus pectoralis) and thigh with drumstick (Tibialis anterior and Biceps femoris) were further analyzed for their physical and chemical characteristics.

\section{Physical analyses}

The $\mathrm{pH}$ values of breast meat and thigh with drumstick were measured using the portable $\mathrm{pH}$ meter (Consort C931, Turnhout, Belgium) equipped with an insertion glass combination electrode (Mettler Toledo Greifensee, Switzerland). Means of twelve measurements were presented. Colour measurements of breast and thigh with drumstick meat were carried out using photo-colorimeter Minolta Chroma Meter CR-400 (Minolta Co., Ltd., Osaka, Japan). Colour characteristics are given in the CIE $L^{*} a^{*} b^{*} \operatorname{system}\left(L^{*}=\right.$ lightness; $a^{*}=$ redness and $b^{*}$ $=$ yellowness). Two measurements were taken on surfaces and cut places of meat samples for each treatment. Data presented are means of 24 measurements. For drip-loss of heat processing determina- tion, samples of meat were measured before heat processing and after the treatment samples were cooled at room temperature for $1 \mathrm{~h}$, and measured in order to determine the loss.

\section{Chemical analyses of meat}

Meat chemical characteristics were determined according to the ISO recommended standards for moisture, protein, fat and ash contents. Data presented are means of twelve measurements.

\section{Statistical analyses}

Statistical analyses were conducted using the statistical software program Statistica 13 for Windows, to determine if variables differed between treatments. Significant effects were further evaluated using analysis of variance (ANOVA), leastsquare means (LSM) and standard errors of leastsquare means ( $\left.\mathrm{SE}_{\mathrm{LSM}}\right)$. Fisher's LSD post-hoc multiple range test with Bonferroni corrections were used to ascertain differences among treatments. A significance level of $p<0.05$ was used.

\section{RESULTS AND DISCUSSION}

Results in this paper are presented in a form of tables with the least square means and standard errors of least-square means, while in available literature there is not sufficient data on meat quality regarding the medicinal plants we used, which makes this investigation a novelty in the field of chicken meat quality. Therefore, the discussion will go in the way of presenting our findings compared with published works regarding the physical and chemical quality of broiler meat.

Results for meat physical characteristics $(\mathrm{pH}$ value, color - CIE $L^{*} a^{*} b^{*}$ values and drip-loss of heat treatment) of all eight dietary treatments are presented in Tables 2 and 3, respectively.

Slightly small numerical average values of breast meat $\mathrm{pH}$ with significant $(\mathrm{p}<0.05)$ differences (ranged from 5.5 to 5.7) which are smaller than 0.3 can be explained as a possible statistical error (Table 2 ). One of the basic tenets of meat science is that accelerated or extended postmortem glycolysis may cause the development of PSE. There are implicit interrelationships between temperature and $\mathrm{pH}$ because glycolysis is exothermic, and the effects of $\mathrm{pH}$ are severe when a carcass is still near body temperature. Meat with a low $\mathrm{pH}$ appears pale because it 
scatters more light back to the observer than meat with a high $\mathrm{pH}$ which appears dark because it transmits more light into its depth than meat with a low $\mathrm{pH}$. In this experiment, the lowest $\mathrm{pH}$ of 5.5 was recorded in breast meat of chicken in dietary treatment $\mathrm{T} 4$ fed $0.5 \mathrm{~g} / 100 \mathrm{~g}$ of black pepper powder, while the highest $\mathrm{pH}$ (5.7) was observed in treatments T2 and T6 with dietary addition of $0.5 \mathrm{~g} / 100$ $\mathrm{g}$ of garlic and hot red pepper powder.

\section{Table 2}

Effect of garlic, black pepper and hot red pepper dietary supplementation on physical parameters of breast meat

\begin{tabular}{lcccccc}
\hline \hline & \multicolumn{5}{c}{ Physical parameters of breast meat } \\
\multicolumn{2}{l}{$\begin{array}{l}\text { Experimental } \\
\text { treatments }\end{array}$} & pH & \multicolumn{3}{c}{ Colour values } & Drip- \\
& & $L^{*}$ & $a^{*}$ & $b^{*}$ & loss \\
\hline $\mathrm{T} 1$ & LSM & $5.6^{\mathrm{ab}}$ & $57.4^{\mathrm{a}}$ & $2.5^{\mathrm{a}}$ & $5.8^{\mathrm{a}}$ & $22.9^{\mathrm{cd}}$ \\
$\mathrm{T} 2$ & LSM & $5.7^{\mathrm{ab}}$ & $57.0^{\mathrm{ab}}$ & $2.5^{\mathrm{a}}$ & $5.4^{\mathrm{a}}$ & $31.4^{\mathrm{a}}$ \\
$\mathrm{T} 3$ & LSM & $5.6^{\mathrm{ab}}$ & $54.3^{\mathrm{ab}}$ & $2.9^{\mathrm{a}}$ & $6.3^{\mathrm{a}}$ & $29.9^{\mathrm{a}}$ \\
$\mathrm{T} 4$ & LSM & $5.5^{\mathrm{b}}$ & $56.5^{\mathrm{ab}}$ & $2.0^{\mathrm{a}}$ & $4.2^{\mathrm{a}}$ & $26.1^{\mathrm{b}}$ \\
$\mathrm{T} 5$ & LSM & $5.6^{\mathrm{ab}}$ & $53.4^{\mathrm{ab}}$ & $2.3^{\mathrm{a}}$ & $4.3^{\mathrm{a}}$ & $23.1^{\mathrm{cd}}$ \\
$\mathrm{T} 6$ & LSM & $5.7^{\mathrm{a}}$ & $53.1^{\mathrm{b}}$ & $2.3^{\mathrm{a}}$ & $3.9^{\mathrm{a}}$ & $20.5^{\mathrm{d}}$ \\
$\mathrm{T} 7$ & LSM & $5.6^{\mathrm{ab}}$ & $57.1^{\mathrm{ab}}$ & $2.4^{\mathrm{a}}$ & $6.3^{\mathrm{a}}$ & $24.3^{\mathrm{bc}}$ \\
$\mathrm{T} 8$ & LSM & $5.6^{\mathrm{ab}}$ & $55.6^{\mathrm{ab}}$ & $2.4^{\mathrm{a}}$ & $4.4^{\mathrm{a}}$ & $31.1^{\mathrm{a}}$ \\
Pooled SELM & 0.04 & 1.38 & 0.49 & 0.87 & 0.93 \\
\hline \hline
\end{tabular}

Means in the same column with a common superscript letter are not significantly different $(\mathrm{p}<0.05)$

When it comes to a CIE $L^{*} a^{*} b^{*}$ color values, from the results given in Table 2 , it can be observed that the differences in $a^{*}$ (redness) and $b^{*}$ (yellowness) color system is present between dietary treatments $\left(a^{*}: 2.0-2.9 ; b^{*}: 3.9-6.3\right)$ but without significant differences $(\mathrm{p}>0.05)$. Colour values for $L^{*}$ (lightness) show significant differences $(p<0.05)$ among dietary treatments. The lowest value for lightness was observed in breast meat of chickens on dietary treatment including $0.5 \mathrm{~g} / 100 \mathrm{~g}$ of hot red pepper, while the highest value for the lightness of breast meat was observed in control treatment. Based on the results of $\mathrm{pH}$ and color values, breast meat could be classified as PSE, but if we take in account the scores of sensory analyses of meat, and that the white meat is in question it could be classified as the meat of normal quality, with the significant influence of dietary spice plants addition.
Heat processing of meat had a significant influence on meat drip-loss $(\mathrm{p}<0.05)$. Hot red pepper in treatment T6 showed the highest positive influence, where the lowest drip-loss of meat after heat treatment was observed $(20.5 \%)$. In the other experimental dietary treatments meat, drip-loss ranged from 23.1 to $31.1 \%$, with the highest value observed in treatment with the addition of $0.5 \mathrm{~g} / 100 \mathrm{~g}$ of garlic powder.

Data on the physical quality of chicken red meat (thigh with drumstick) are shown in Table 3.

\section{Table 3}

\section{Effect of garlic, black pepper and hot red pepper dietary supplementation on physical parameters of the thigh with drumstick}

\begin{tabular}{|c|c|c|c|c|c|c|}
\hline \multirow{3}{*}{\multicolumn{2}{|c|}{$\begin{array}{l}\text { Experimental } \\
\text { treatments }\end{array}$}} & \multicolumn{5}{|c|}{$\begin{array}{c}\text { Physical parameters of the thigh with } \\
\text { drumstick }\end{array}$} \\
\hline & & \multirow{2}{*}{$\mathrm{pH}$} & \multicolumn{3}{|c|}{ Colour values } & \multirow{2}{*}{ Drip-loss } \\
\hline & & & $L^{*}$ & $a^{*}$ & $b^{*}$ & \\
\hline $\mathrm{T} 1$ & LSM & $6.0^{\mathrm{ab}}$ & $61.0^{\mathrm{a}}$ & $3.6^{\mathrm{ab}}$ & $5.4^{\mathrm{ab}}$ & $30.2^{\mathrm{ab}}$ \\
\hline $\mathrm{T} 2$ & LSM & $6.0^{\mathrm{ab}}$ & $60.7^{\mathrm{ab}}$ & $2.9^{\mathrm{bc}}$ & $6.2^{\mathrm{a}}$ & $31.2^{\mathrm{a}}$ \\
\hline $\mathrm{T} 3$ & LSM & $6.0^{\mathrm{ab}}$ & $57.2^{\mathrm{bc}}$ & $2.4^{\mathrm{bc}}$ & $4.2^{\mathrm{ab}}$ & $31.6^{\mathrm{a}}$ \\
\hline $\mathrm{T} 4$ & LSM & $5.9^{\mathrm{b}}$ & $60.3^{\mathrm{abc}}$ & $2.3^{\mathrm{c}}$ & $4.4^{\mathrm{ab}}$ & $32.6^{\mathrm{a}}$ \\
\hline T5 & LSM & $6.0^{\mathrm{ab}}$ & $57.0^{c}$ & $2.4^{\mathrm{bc}}$ & $4.5^{\mathrm{ab}}$ & $31.1^{\mathrm{a}}$ \\
\hline T6 & LSM & $6.0^{\mathrm{a}}$ & $58.9^{\mathrm{abc}}$ & $2.9^{\mathrm{bc}}$ & $3.6^{\mathrm{b}}$ & $33.7^{\mathrm{a}}$ \\
\hline $\mathrm{T} 7$ & LSM & $5.9^{\mathrm{ab}}$ & $58.2^{\mathrm{abc}}$ & $4.2^{\mathrm{a}}$ & $5.5^{\mathrm{ab}}$ & $27.3^{\mathrm{b}}$ \\
\hline $\mathrm{T} 8$ & LSM & $5.9^{\mathrm{ab}}$ & $59.0^{\mathrm{abc}}$ & $3.2^{\mathrm{abc}}$ & $5.3^{\mathrm{ab}}$ & $31.9^{\mathrm{a}}$ \\
\hline \multicolumn{2}{|c|}{ Pooled SELSM } & 0.04 & 1.21 & 0.44 & 0.74 & 1.2 \\
\hline
\end{tabular}

Means in the same column with a common superscript letter are not significantly different $(\mathrm{p}<0.05)$

From our findings, it can be noticed a very small average difference in $\mathrm{pH}$ values, but with significant differences $(\mathrm{p}<0.05)$, as it was the case with breast meat. Values of $\mathrm{pH}$ ranged from 5.9 to 6.0 , so the thigh with drumstick can be classified as normal quality meat. The highest value of redness $\left(a^{*}\right)$ was observed in treatment with the addition of $1.0 \mathrm{~g} / 100$ $\mathrm{g}$ of hot red pepper with significant $(\mathrm{p}<0.05)$ differences compared to other experimental dietary treatments. The lowest $a^{*}$ value was recorded in treatment $\mathrm{T} 4$ with the addition of black pepper powder. Contrary to white meat, significant differences $(\mathrm{p}<0.05)$ were observed and in $b^{*}$ color values of the thigh and drumstick meat, which ranged from 4.2 (T3) to 6.2 (T2), respectively. The highest lightness (61.0) combined with high redness (3.6) was observed in meat of control treatment $(\mathrm{p}<0.05)$ and 
it could be classified as reddish, soft and exudative (RSE) meat, while the addition of spices especially hot red pepper had positive influence of red meat, which could be classified as normal.

The dietary addition of hot red pepper also shows its positive influence on meat drip-loss after heat treatment. Experimental treatment $\mathrm{T} 7 \mathrm{recorded}$ the lowest drip-loss value (27.3\%).

Considering the glycolytic process, initial $\mathrm{pH}$ value provides the best information for physiological meat quality. Highly accelerated as well as accelerated $\mathrm{pH}$ decline are related to a light meat color and poor juice retention, which in the majority of cases is the same for $\mathrm{pH}$ values ranging from 5.8 to 6.0 concerning exudative meat composition. Besides $\mathrm{pH}$ value, many other sensories, instrumental and biophysical methods are involved in the determination of chicken meat quality [19]. During recent years, deviations in meat quality which did not show typical characteristics of PSE and DFD were repeatedly reported. There was acceptable color and increased wateriness (RSE) as well as pale color and good juice retention (PFN). Of especially interest is RSE meat, as drip-loss means a loss in weight and therefore economic losses. In our experiment, $\mathrm{pH}$ value of chickens breast meat ranged from 5.5 to 5.7 and in thigh and drumstick between 5.9 and 6.0 with observed significant $(\mathrm{p}<0.05)$ differences, while the Qiao et al. [20] in their investigation reported $\mathrm{pH}$ values of the lighter thannormal, normal and darker-than-normal groups with $5.81,5.96$, and 6.23 , respecttively, which were significantly different from each other. Stanaćev et al. [21] recorded a $\mathrm{pH}$ value of 5.6 in meat from chickens fed $2 \%$ of garlic powder. According to Karunanayaka et al. [22], meat with a $\mathrm{pH}$ higher than 5.8 is classified as normal meat quality. Several researchers have demonstrated a significant relationship between raw meat color and raw meat $\mathrm{pH}$. Barbut [17] reported that lightness $\left(L^{*}\right)$ had the highest correlation of the $L^{*}, a^{*}, b^{*}$ color values with PSE conditions. In our experiment, the dietary addition of garlic, black pepper and hot red pepper had an influence on broiler chicken meat color. The relationship between muscle $\mathrm{pH}$, color, and meat quality in red meat species is well established. As noted earlier, the relationship between poultry meat color and $\mathrm{pH}$ has also been well documented, but the relative influence on poultry meat quality is not as well established as in the extremes of PSE and DFD conditions in pork and beef [20]. The positive influence of medicinal plants addition in broiler chicken diet on meat quality was also observed by
Savković et al. [23] using a mixture of different spice and aromatic herbs. Hot red pepper in the current experiment showed the highest positive influence with the lowest drip-loss of breast meat after heat treatment $(20.5 \%)$, while the higher addition of the same spice (T7) in the thigh with drumstick also showed the positive influence and lowest drip-loss of $27.3 \%$. Allen et al. (1998) reported that initial and tumbled $L^{*}$ values are correlated positively with drip-loss and cook-loss of chicken meat. Their results were in agreement with the previous findings of Barbut [17], who observed a high correlation between $L^{*}$ and cooking loss, whereas the Allen et al. [24] found no correlation between raw meat $\mathrm{pH}$ and drip-loss or cook-loss. In our trial, the highest drip-loss of breast meat was observed in treatment T2 with $L^{*}$ of 57.0 and in treatment T6 with $L^{*}$ of 58.9 of red meat, which is in agreement with earlier findings.

From the results given in Table 4, it can be observed no significant $(\mathrm{p}>0.05)$ differences in moisture content in both breast and thigh with drumstick meat. Moisture in white meat ranged from 71.8 to $73.9 \mathrm{~g} / 100 \mathrm{~g}$ and 72.5 to $74.8 \mathrm{~g} / 100 \mathrm{~g}$ in red meat, respectively. The highest content of protein $(24.0 \mathrm{~g} /$ $100 \mathrm{~g}$ ) was observed in treatment T5 with significant $(\mathrm{p}<0.05)$ differences compared to treatments T2 (22.3), T1 (22.1) and T8 (21.8 g/100 g), respectively. The lowest amount of fat was observed in treatment T5 $(0.16 \mathrm{~g} / 100 \mathrm{~g})$ what was expected because of the negative correlations between the content of protein and fat. The highest fat content was recorded in control treatment T1 $(0.55 \mathrm{~g} / 100 \mathrm{~g})$ with significant $(\mathrm{p}<0.05)$ differences compared to the other treatments. Significant differences between the groups $(p<0.05)$ were found in the ash content of both breast meat and thigh with drumstick meat. The highest content of protein (20.6 $\mathrm{g} / 100 \mathrm{~g}$ ) in thighs with drumsticks was observed in dietary treatment with the addition of hot red pepper (T7). Interesting is that the same treatment also contains the highest content of fat $(3.86 \mathrm{~g} / 100 \mathrm{~g})$. This could be explained by the influence of capsaicin as the active compound in hot red pepper on the metabolism of fat and the highest utilization from the feed which is incorporated in the body. The lowest content of protein in meat, as in the breast meat was observed in control treatment $(18.6 \mathrm{~g} / 100 \mathrm{~g})$ with the fat content of $2.59 \mathrm{~g} / 100 \mathrm{~g}$, which could be a sign of the positive influence of dietary medicinal plants addition to alteration of chicken meat nutritive quality. 
Table 4

Effect of garlic, black pepper and hot red pepper dietary supplementation on the chemical characteristic of breast meat and thigh with drumstick

\begin{tabular}{cccccccccc}
\hline \multicolumn{2}{c}{$\begin{array}{c}\text { Experimental } \\
\text { treatments }\end{array}$} & \multicolumn{3}{c}{ Quality parameters of breast meat } & \multicolumn{3}{c}{ Quality parameters of the thigh with drumstick } \\
& Moisture & Protein & Fat & Ash & Moisture & Protein & Fat & Ash \\
\hline T1 & LSM & $73.8^{\mathrm{a}}$ & $22.1^{\mathrm{b}}$ & $0.55^{\mathrm{a}}$ & $1.12^{\mathrm{bc}}$ & $74.7^{\mathrm{a}}$ & $18.6^{\mathrm{b}}$ & $2.59^{\mathrm{e}}$ & $1.00^{\mathrm{b}}$ \\
T2 & LSM & $73.4^{\mathrm{a}}$ & $22.3^{\mathrm{b}}$ & $0.48^{\mathrm{b}}$ & $1.19^{\mathrm{ab}}$ & $74.3^{\mathrm{a}}$ & $18.7^{\mathrm{b}}$ & $3.74^{\mathrm{a}}$ & $1.06^{\mathrm{a}}$ \\
T3 & LSM & $73.9^{\mathrm{a}}$ & $22.6^{\mathrm{ab}}$ & $0.30^{\mathrm{c}}$ & $1.18^{\mathrm{ab}}$ & $72.7^{\mathrm{a}}$ & $19.8^{\mathrm{ab}}$ & $2.79^{\mathrm{d}}$ & $1.09^{\mathrm{a}}$ \\
T4 & LSM & $73.3^{\mathrm{a}}$ & $22.6^{\mathrm{ab}}$ & $0.28^{\mathrm{c}}$ & $1.16^{\mathrm{abc}}$ & $74.2^{\mathrm{a}}$ & $19.4^{\mathrm{ab}}$ & $2.99^{\mathrm{c}}$ & $1.00^{\mathrm{b}}$ \\
T5 & LSM & $72.3^{\mathrm{a}}$ & $24.0^{\mathrm{a}}$ & $0.16^{\mathrm{d}}$ & $1.24^{\mathrm{a}}$ & $72.5^{\mathrm{a}}$ & $20.0^{\mathrm{a}}$ & $2.26^{\mathrm{f}}$ & $1.07^{\mathrm{a}}$ \\
T6 & LSM & $71.8^{\mathrm{a}}$ & $22.7^{\mathrm{ab}}$ & $0.49^{\mathrm{b}}$ & $1.17^{\mathrm{ab}}$ & $74.3^{\mathrm{a}}$ & $19.5^{\mathrm{ab}}$ & $3.24^{\mathrm{b}}$ & $1.08^{\mathrm{a}}$ \\
T7 & LSM & $72.6^{\mathrm{a}}$ & $21.8^{\mathrm{b}}$ & $0.18^{\mathrm{d}}$ & $1.06^{\mathrm{c}}$ & $73.3^{\mathrm{a}}$ & $20.6^{\mathrm{a}}$ & $3.68^{\mathrm{a}}$ & $1.06^{\mathrm{a}}$ \\
Pooled SE & 0.81 & 0.53 & 0.02 & 0.02 & 0.81 & 0.44 & 0.04 & 0.02 \\
\hline \hline
\end{tabular}

Means in the same column with a common superscript letter are not significantly different $(\mathrm{p}<0.05)$

The moisture content of white and red meat was almost equal among dietary groups. Similarly, research reported that broiler chickens feed supplementation with Echinacea (Echinacea purpurea), garlic (Allium sativum) and ginger (Zingiber officinale) resulted in no effect on meat moisture content. In our experiment, the highest protein content of breast $(24.0 \mathrm{~g} / 100 \mathrm{~g})$ and thigh with drumstick (20.6 $\mathrm{g} / 100 \mathrm{~g}$ ) meat were observed in treatments T5 and T6, respectively. From this fact, it can be noticed that the dietary addition of black pepper and hot red pepper to chicken ration led to significant improvement of meat quality. In previous research of Stanaćev et al. [21], dietary garlic powder addition to chickens diet at a level of $2.0 \mathrm{~g} / 100 \mathrm{~g}$, resulted in significant differences in protein content (22.9 $\mathrm{g} / 100 \mathrm{~g}$ ) in breast meat compared to control diet $(21.8 \mathrm{~g} / 100 \mathrm{~g})$. The lowest protein content of 18.6 $\mathrm{g} / 100 \mathrm{~g}$ was observed in red meat from the control treatment. Souza et al. (2011) reported that the protein content of chicken breast meat ranged from 22.48 to $22.61 \mathrm{~g} / 100 \mathrm{~g}$ without significant differences.

Content of protein in chicken breast meat in the range from 20.7 to $32.1 \%$ was reported by Mohammed [25] with energy value between 160.0 and $212.0 \mathrm{kcal}$. Onibi et al. [26] reported a significant influence of spice and herbs in broiler nutrition on fat content, where the thigh muscle had the highest fat content $(82.9 \mathrm{~g} / \mathrm{kg})$, followed by drumstick muscle $(66.9 \mathrm{~g} / \mathrm{kg})$ and lowest for breast muscle $(49.1$ $\mathrm{g} / \mathrm{kg}$ ). The lowest fat content of breast meat in the current experiment was recorded when birds fed 1.0 $\mathrm{g} / 100 \mathrm{~g}$ of black pepper powder $(0.16 \mathrm{~g} / 100 \mathrm{~g})$ and
$2.13 \mathrm{~g} / 100 \mathrm{~g}$ in red meat of chicken fed with a mixture of garlic, black pepper and hot red pepper powder at $0.5 \mathrm{~g} / 100 \mathrm{~g}$. Similarly, fat deposition has been reported to be higher in red meat than in breast meat. Breast meat fat content was affected by the interaction between sex and genetic strain, with males presenting the highest values as found by Souza et al. [27]. On the other hand, Lonergan et al. (2003) reported higher fat content values in females as influenced by the interaction between sex and the genetic group fed with the same dietary mixtures. The addition of black pepper powder had a high influence on the mineral content of breast meat in our experiment. The significantly higher ash content of chicken meat was reported by Mohammed [25] who is in accordance with our results.

\section{CONCLUSIONS}

Based on our findings, it can be concluded that the dietary addition of garlic, black pepper, and hot red pepper to broiler diet showed significant influence in the improvement of physical and chemical characteristics of meat. Moreover, it can be concluded that administrative and technological as well as the nutritional quality of chicken meat can only be reached with proven feed supplements, because of not all of the additives may have beneficial effects on meat quality, but can have the opposite tendency. From this trial, the used medicinal plants showed a significant effect on chicken meat quality, but the knowledge of their use is still limited, and thus further investigation is still necessary. 
Acknowledgements: The paper is a part of the research work on project III 46012 financed by the Ministry of Education, Science and Technological Development of the Republic of Serbia.

\section{REFERENCES}

[1] Puvača, N.: Bioactive compounds in selected hot spices and medicinal plants. J. Agron. Technol. Eng. Manag., 1, 8-17 (2018).

[2] Puvača, N., Ljubojević Pelić, D., Popović, S., Ikonić, P., Đuragić, O., Peulić, T., Lević, J.: Evaluation of broiler chickens lipid profile influenced by dietary chili pepper addition. J. Agron. Technol. Eng. Manag., 2 (5), 318-324 (2019).

[3] Giannenas, I., Bonos, E., Christaki, E., Florou-Paneri, P. Essential oils and their applications in animal nutrition. Med. Aromat. Plants., 2, 1-12 (2013).

[4] Puvača, N., Čabarkapa, I., Petrović, A., Bursić, V., Prodanović, R., Soleša, D., Lević, J.: Tea tree (Melaleuca alternifolia) and its essential oil: antimicrobial, antioxidant and acaricidal effects in poultry production. Worlds Poult. Sci., 75, 235-246 (2019).

[5] Puvača, N., Kostadinović, Lj., Ljubojević, D., Lukač, D., Lević, J., Popović, S., Novakov, N., Vidović, B., Đuragić, O.: Effect of garlic, black pepper and hot red pepper on productive performances and blood lipid profile of broiler chickens. Eur. Poultry Sci., 79, DOI: 10.1399/eps.2015.73 (2015).

[6] Popović, S., Kostadinović, Lj., Đuragić, O., Aćimović, M., Čabarkapa, I., Puvača, N., Ljubojević Pelić, D.: Influence of medicinal plants mixtures (Artemisia absinthium, Thymus vulgaris, Menthae piperitae and Thymus serpyllum) in broilers nutrition on biochemical blood status. J. Agron. Technol. Eng. Manag., 1, 91-98 (2018).

[7] Kostadinović, Lj., Lević, J., Popović, S., Čabarkapa, I., Puvača, N., Đuragić, O., Kormanjoš, S.: Dietary inclusion of Artemisia absinthium for management of growth performance, antioxidative status and quality of poultry meat. Eur. Poultry Sci., 79, DOI: 10.1399/eps.2015.75 (2015).

[8] Puvača, N., Čabarkapa, I., Bursić, V., Petrović, A., Aćimović, M.: Antimicrobial, antioxidant and acaricidal properties of tea tree (Melaleuca alternifolia). J. Agron. Technol. Eng. Manag., 1, 29-38 (2018).

[9] Puvača, N., Stanaćev, V., Glamočić, D., Lević, J., Perić, L., Stanaćev, V., Milić, D.: Beneficial effects of phytoadditives in broiler nutrition. Worlds Poult. Sci., 69, 27-34 (2013).

[10] Najafi, P., Torki, M.: Performance, blood metabolites and immunocompetaence of broiler chicks fed diets included essential oils of medicinal herbs. Asian J. Anim. Vet. Adv., 9, 1164-1168 (2010).

[11] Džinić, N., Puvača, N., Tasić, T., Ikonić, P., Okanović, Đ.: How meat quality and sensory perception is influenced by feeding poultry plant extracts. Worlds Poult. Sci. J., 71, 673-681 (2015).

[12] Puvača, N., Kostadinović, Lj., Popović, S., Lević, J., Ljubojević, D., Tufarelli, V., Jovanović, R., Tasić, T., Ikonić, P., Lukač, D.: Proximate composition, cholesterol concentration and lipid oxidation of meat from chickens fed dietary spice addition (Allium sativum, Piper nigrum, Capsicum annuum). Anim. Prod. Sci., 56, 1920-1927 (2016).

[13] Spasevski, N., Puvača, N., Pezo, L., Tasić, T., Vukmirović, Đ., Banjac, V., Čolović, R., Rakita, S., Kokić, B., Džinić, N.: Optimisation of egg yolk colour using natural colourants. Eur. Poultry Sci., 82, DOI: 10.1399/eps.2018.246 (2018).

[14] Govaris, A., Botsoglou, N., Papageorgiou, G., Botsoglou, E., Amvrosiadis, I.: Dietary versus postmortem use of oregano oil and/or $\alpha$-tocopherol in turkeys to inhibit development of lipid oxidation in meat during refrigerated storage. Int. J. Food Sci. Nutr., 55, 115-123 (2004).

[15] Puvača, N., Stanaćev, V.: Selenium in poultry nutrition and its effect on meat quality. Worlds Poult. Sci., 67, 479-484 (2011).

[16] Khalafalla, F. A., Fatma, H. M., Dalia, A., Zahran, A., Mosa, A. M. M. A.: Influence of feed additives in quality of broiler carcasses. J. Worlds Poult. Res., 2, 40-47 (2011).

[17] Barbut, S.: Colour measurements for evaluating the pale soft exudative (PSE) occurrence in turkey meat. Food Res. Int., 26, 39-43 (1993).

[18] Laudadio, V., Tufarelli, V.: Pea (Pisum sativum L.) seeds as an alternative dietary protein source for broilers: Influence on fatty acid composition, lipid and protein oxidation of dark and white meats. J. Am. Oil Chem. Soc., 88, 967973 (2011)

[19] Damez, J. L., Clerjon, S.: Meat quality assessment using biophysical methods related to meat structure. Meat Sci. 80, 132-149 (2008).

[20] Qiao, M., Fletcher, D. L., Smith, D. P., Northcutt, J. K.: The effect of broiler breast meat color on $\mathrm{pH}$, moisture, water-holding capacity, and emulsification capacity. Poult. Sci., 80, 676-680 (2001).

[21] Stanaćev, V., Glamočić, D., Milošević, N., Puvača, N., Stanaćev, V., Plavša, N.: Effect of garlic (Allium sativum L.) in fattening chicks nutrition. Afr. J. Agric. Res., 6, $943-$ 948 (2011)

[22] Karunanayaka, D. S., Jayasena, D. D., Jo, C.: Prevalence of pale, soft, and exudative (PSE) condition in chicken meat used for commercial meat processing and its effect on roasted chicken breast. J. Anim. Sci. Tech., 58, DOI: 10.1186/s40781-016-0110-8 (2016).

[23] Savković, T., Džinić, N., Tojagić, S.: Herbs as the addition to broiler's nutrition and sensoric quality of broiler's meat. Meat Tech., 49, 75-81 (2008).

[24] Allen, C.D., Fletcher, D.L., Northcutt, J.K., Russell, S.M.: The relationship of broiler breast color to meat quality and shelf-life. Poult. Sci., 77, 361-366 (1998).

[25] Mohammed, H.N.: Study of some chemical, physical, sensory and bacteriology characteristics of canned chicken meat imported to Sulaymaniyah markets, Iraq. Int. J. Nutr. Met., 5, 128-133 (2013).

[26] Onibi, G. E., Adebisi, O. E., Fajemisin, A. N., Adetunji, A. V.: Response of broiler chickens in terms of performance and meat quality to garlic (Allium sativum) supplementation. Afr. J. Agric. Res., 4, 511-517 (2009).

[27] Souza, X. R., Faria, P. B., Bressan, M. C.: Proximate composition and meat quality of broilers reared under different production systems. Braz. J. Poultry Sci., 13, 15-20 (2011) 
